\title{
Template Matching dalam Otomatisasi Penghitung Sel Keping Darah Berbasis Image Processing untuk Deteksi Dini Derajat Penyakit Demam Berdarah
}

\section{Template Matching in the Automation of Counter Platelets Based of Image Processing for The Early Detection of Dengue Fever Degree}

\author{
Amelia Yolanda $^{1)}$, Deddy Prayama ${ }^{2)}$ \& Aulia Ramadhani ${ }^{3)}$ \\ ${ }^{1)}$ Staf Pengajar Teknik Telekomunikasi, Jurusan Teknik Elektro, Politeknik Negeri Padang \\ Telp. 0751-72590 Fax.0751-72590 Email: amelia@pnp.ac.id \\ ${ }^{2}$ Staf Pengajar Teknik Komputer, Jurusan Teknologi Informatika, Politeknik Negeri Padang \\ Telp.0751-72590 Fax.0751-72590 Email: deddy@pnp.ac.id \\ ${ }^{3)}$ Mahasiswa Teknik Telekomunikasi, Jurusan Teknik Elektro, Politeknik Negeri Padang \\ Email: auliaramadhani0597@gmail.com
}

\begin{abstract}
One of the diseases that can be detected through blood tests is Dengue Hemorrhagic Fever (DHF). The number of platelets are one of the guidelines used by doctors diagnosing DHF. Actually, platelets can be calculated manually, but it will be very difficult if the platelets are counted quite a lot. So, we need a technology that can calculate the number of platelets quickly and automatized to get more accurate results.
\end{abstract}

The automatic systems built by using the template matching method with image processing include HSL Segmentation with Luminance type and Reverse Color Manipulation. After building the system, the system will automatically look for objects that match the template in the sample image and then give the marking and calculate it.

The overall system testing results are the number of platelets which are then classified manually at what degree of $\mathrm{DHF}$.

Keywords : DHF, Platelets, Thrombocytopenia, Template Matching, Blood Cells

\section{PENDAHULUAN}

Salah satu jaringan ikat dalam tubuh manusia adalah darah. Darah menghubungkan organ-organ di dalam tubuh manusia melalui pembuluh-pembuluh darah. Oleh karena itu indikasi keadaan tubuh dan pendeteksian berbagai penyakit dapat diketahui melalui pemeriksaan darah. Meskipun banyak cara lain yang dapat dilakukan dalam mendeteksi penyakit seperti air ludah, urin atau iris mata, darah masih menjadi sumber diagnosa yang paling dapat diandalkan. Hal ini dikarenakan banyaknya informasi yang terkandung dalam darah. Sebagai perbandingan, kadar zat tertentu yang terkandung dalam air ludah hanya seperseratus sampai seperseribu dari apa yang dapat ditemukan di dalam darah.
Penyakit yang indikasinya dapat diketahui melalui pemeriksaan darah adalah Demam Berdarah Dengue (DBD). Demam berdarah adalah suatu penyakit infeksi yang disebabkan oleh virus dengue yang ditularkan melalui nyamuk. Nyamuk yang dapat menularkan penyakit demam berdarah adalah nyamuk Aedes Aegypti dan Aedes Albopictus. Penyakit ini merupakan penyakit yang timbul di negara-negara tropis termasuk Indonesia.

Jumlah trombosit darah merupakan salah satu acuan yang digunakan dokter dalam diagnosa penyakit DBD. Trombosit sendiri adalah komponen darah yang bertanggung jawab dalam proses pembekuan darah. Saat trombosit terus menurun hingga tidak dapat menghentikan 
rembesan plasma akibat bocornya pembuluh kapiler, maka terjadilah pendarahan.

Pemeriksaan laboratorium dalam hal ini darah menjadi data penunjang diagnosa klinis jika diperlukan. Diagnosa yang cepat dan tepat sangat diperlukan dalam penanganan suatu kasus penyakit. Hal ini untuk mempercepat tindakan yang perlu dilakukan guna meminimalisir potensi kematian pada pasien. Oleh karena itu tuntutan akan teknologi yang mampu membantu pelaksanaan diagnosis secara cepat, mudah dan teliti semakin besar.

Jumlah sel darah \{ sel darah merah (eritrosit), sel darah putih (leukosit) dan keping-keping darah (trombosit)\} sebenarnya dapat dihitung dengan cara manual. Tetapi bila sel darah yang dihitung cukup banyak akan memakan waktu. Hal ini menyebabkan perhitungan secara manual tidak efisien. Selain itu, perhitungan secara manual terhadang kurang akurat karena dilakukan dengan pengamatan langsung, hal ini disebabkan karena pengamatan pada sel darah sangat dipengaruhi oleh tingkat ketelitian dokter yang menganalisa. Oleh karena itu diperlukan suatu teknologi yang dapat menghitung jumlah sel darah secara cepat dan terautomatisasi sehingga mendapatkan hasil yang lebih akurat.

Sebelumnya telah pernah dilakukan penelitian oleh beberapa orang mengenai topik terkait diantaranya Simulasi Penghitungan Sel Darah Merah yang dilakukan dengan penambahan 3 jenis derau yaitu speckle, gaussian dan salt and pepper (Sugianto, Soegeng, dkk, 2010). Metode yang digunakan dalam pengenalan objek adalah pengambangan (pemisahan latar dan objek) dan penyapuan (filter objek berdasarkan ukuran). Terakhir, hasil yang didapat adalah penghitungan objek dari hasil penyapuan. Penelitian selanjutnya dengan judul Penghitungan Otomatis Jumlah Sel Darah Merah dan Identifikasi Fase Plasmodium Falsiparum Menggunakan Operasi Morfologi [8]. Sesuai judulnya, percobaan ini menggunakan operasi morfologi dengan identifikasi fase plasmodium falciparum dilakukan dengan cara melakukan ekstraksi ciri morfologi parasit. Percobaan ini sendiri diperuntukan untuk pengenalan penyakit malaria. Hasil pada percobaan ini berupa perhitungan jumlah sel darah merah dan jumlah parasit serta penentuan parasit tersebut sudah berada pada tingkatan fase pertumbuhan apa berdasarkan ukuran dan bentuknya.

Penelitian ini bertujuan untuk melakukan template matching dalam otomatisasi penghitungan keping darah berbasis image processing untuk pendeteksian dini derajat penyakit DBD.

\section{METODOLOGI}

Berdasarkan tujuan dan manfaat yang ingin dicapai dalam penelitian ini yaitu melakukan penelitian terhadap kegunaan metode segmentasi dalam menghitung jumlah trombosit dalam suatu sampel darah, dan nantinya diharapkan penelitian ini dapat bermanfaat di bidang kedokteran pada umumnya (Hifzi, 2008). Jika ditinjau dari tujuan dasarnya maka penelitian ini termasuk ke dalam jenis penelitian terapan, bahwa penelitian ini merupakan pecahan terhadap suatu masalah untuk tujuan tertentu dan merupakan aplikasi baru dari penelitian yang telah ada dengan berpedoman pada data sekunder (data hasil penelitian) yang relevan. Sedangkan jika ditinjau dari sifat-sifat masalahnya maka penelitian ini bersifat simulasi.

Penelitian ini dirancang agar dapat melakukan segmentasi terhadap citra sel darah, yaitu melakukan pemisahan antara objek sel darah yang satu dengan yang lainnya (antara sel darah putih normal dan sel darah putih terkena demam berdarah). (Y. Amelia, K. Rahmadi, 2015). Penelitian ini dimulai dengan pembacaan citra darah sebagai input. Proses dilanjutkan dengan segmentasi yaitu proses pengelompokan citra digital ke beberapa daerah atau bagian tertentu dengan tujuan untuk menyederhanakan ataupun merubah representasi gambar menjadi sesuatu yang 
lebih bermakna dan mudah dianalisa ( $\mathrm{R}$. Adollah, 2008).

Metode segmentasi yang digunakan adalah segmentasi jenis Hue Saturation Lightnes atau yang dikenal juga dengan Hue Saturation and Luminosity/ Luminance yaitu yaitu segmentasi berdasarkan komponen warna RGB.. Kemudian dilakukan pembuatan Pattern Warna (template) yang akan dideteksi dan kemudian hasil dari pattern warna tersebut disimpan dalam format JPEG dan atau PNG.

Proses selanjutnya adalah Contour Location yaitu proses pencarian warna yang sesuai dengan template pada citra input. Proses perhitungan jumlah pattern yang sesuai template bertujuan untuk menghitung objek dengan warna yang sesuai dengan template pada citra input. Proses perhitungan jumlah pattern yang sesuai template bertujuan untuk menghitung objek dengan warna yang sesuai dengan template warna, selanjutnya akan dihitung jumlah trombosit yang sesuai dengan template. Proses ini akan menghasilkan jumlah lokasi warna yang sesuai dengan template. Menandai objek bertujuan untuk menandai lokasi warna yang sesuai dengan template. Proses ini menggunakan koordinat yang didapatkan dari proses sebelumnya.

\section{Citra}

Secara harfiah, citra (image) adalah gambar pada bidang dwimatra (dua dimensi) (Hifzi, 2008). Ditinjau dari sudut pandang matematis, citra merupakan fungsi menerus (continue) dari intensitas cahaya pada bidang dwimatra.

Citra sebagai keluaran dari suatu sistem perekaman data dapat bersifat (Hifzi, 2008) :

1. Optik berupa foto.

2. Analog berupa sinyal video seperti gambar pada monitor televisi.

3. Digital yang dapat langsung disimpan pada suatu pita magnetik.

\section{Pembentukan Citra}

Proses pembentukan citra dapat diilustrasikan dengan gambar dibawah ini.

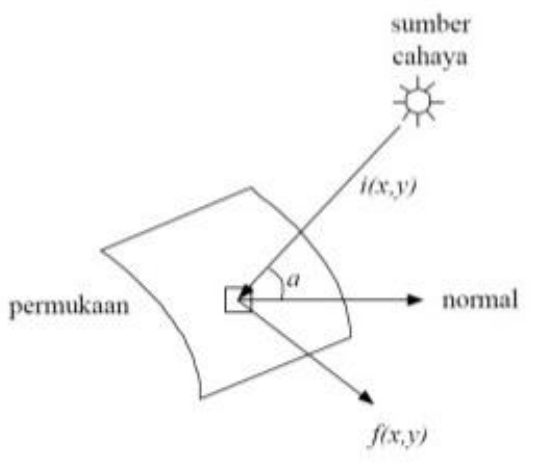

Gambar 1. Proses pembentukan citra

Sumber cahaya menyinari permukaan objek. Jumlah pancaran (iluminasi) cahaya yang diterima objek pada koordinat $(x, y)$ adalah $i(x, y)$. Objek memantulkan cahaya yang diterimanya dengan derajat pantulan $\mathrm{r}$ $(x, y)$. Hasil kali antara $i(x, y)$ dan $\mathrm{r}(x, y)$ menyatakan intensitas cahaya pada koordinat $(x, y)$ yang ditangkap oleh sensor visual pada sistem optik, sehingga :

$$
f(x, y)=i(x, y) \cdot r(x, y)
$$

Nilai i $(x, y)$ ditentukan oleh sumber cahaya, sedangkan $\mathrm{r}(\mathrm{x}, \mathrm{y})$ ditentukan oleh karakteristik objek dalam gambar. Nilai $r$ $(\mathrm{x}, \mathrm{y})=0$ mengidentifikasikan penyerapan total, sedangkan $\mathrm{r}(\mathrm{x}, \mathrm{y})=1$ menyatakan pemantulan total. Jika permukaan mempunyai derajat pemantulan nol, maka fungsi intensitas cahaya $\mathrm{f}(\mathrm{x}, \mathrm{y})$ juga nol. Sebaliknya, jika permukaan mempunyai derajat pemantulan 1, maka fungsi intensitas cahaya sama dengan iluminasi yang diterima oleh permukaan tersebut.

\section{Digitalisasi Citra}

Agar dapat diolah dengan komputer digital, maka suatu citra harus direpresentasikan secara numerik dengan nilai-nilai diskrit (Munir, 2004). Proses representasi citra dari fungsi malar (kontinu) menjadi nilai-nilai diskrit disebut digitalisasi. Pada umumnya citra digital berbentuk persegi panjang, dan dimensi 
ukurannya dinyatakan sebagai tinggi x lebar (atau panjang x lebar).

Citra digital yang tingginya $\mathrm{N}$, lebarnya $\mathrm{M}$, dan memiliki L derajat keabuan dapat dianggap sebagai fungsi :

$$
f(x, y)\left\{\begin{array}{l}
0 \leq x \leq M \\
0 \leq y \leq N \\
0 \leq f \leq L
\end{array}\right.
$$

Citra digital yang berukuran $N x M$ lazimnya dinyatakan dengan matriks yang berukuran $N$ baris $M$ kolom sebagai berikut (Munir, 2004) :

$$
f(x, y) \approx\left[\begin{array}{cccc}
f(0,0) & f(0,1) & \ldots & f(0, M) \\
f(1,0) & f(1,1) & \ldots & f(1, M) \\
\cdot & . & \ldots & . \\
f(N-1,0) & f(N-1,1) & \ldots & f(N-1, M-1)
\end{array}\right]
$$

Indeks baris $(i)$ dan indeks kolom $(f)$ menyatakan suatu koordinat titik pada citra, sedangkan $f(i, j)$ merupakan intensitas (derajat keabuan) pada titik $(i, j)$. Sebagai contoh, misalkan sebuah citra berukuran 256x256 piksel dan direpresentasikan secara numerik dengan matriks yang terdiri dari 256 baris (di indeks dari 0 sampai 255) dan 256 kolom (di indeks 0 sampai 255) seperti contoh berikut :

$$
\left(\begin{array}{cccc}
0 & 134 & \ldots & 231 \\
0 & 167 & \ldots & 197 \\
\vdots & \vdots & \vdots & \vdots \\
221 & 219 & \ldots & 156
\end{array}\right)
$$

Piksel pertama pada koordinat $(0,0)$ mempunyai nilai intensitas 0 yang berarti warna piksel tersebut hitam, piksel kedua pada koordinat $(0,1)$ mempunyai intensitas 134 yang berarti warnanya antara hitam dan putih, dan seterusnya.

\section{Template Matching}

Template matching adalah sebuah teknik dalam pengolahan citra digital untuk menemukan bagian-bagian kecil dari gambar yang cocok dengan template gambar. Template matching merupakan salah satu ide yang digunakan untuk menjelaskan bagaimana otak kita mengenali kembali bentuk-bentuk atau pola-pola. Contoh template matching dapat dilihat pada gambar 2 berikut ini :

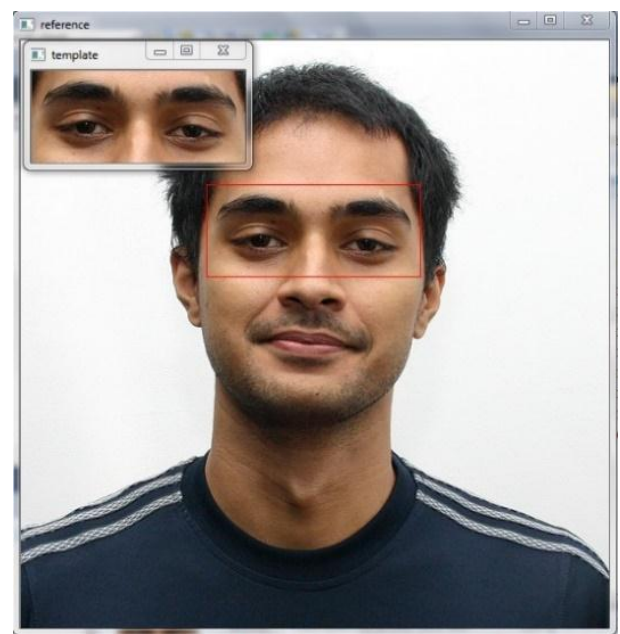

Gambar 2. Template Matching

Teori template matching memiliki keunggulan dan kelemahan diantaranya :

\section{Keunggulan}

1. Jelas bahwa untuk mengenal bentuk, huruf atau bentuk-bentuk visual lainnya diperlukan kontak dengan bentuk-bentuk internal.

2. Template matching adalah prosedur pengenalan pola yang sederhana yang didasarkan pada ketepatan konfigurasi informasi penginderaan dengan "konfigurasi" pada otak. (Contohnya : barcode)

\section{Kelemahan}

Jika perbandingan eksternal objek dgn internal objek 1:1, maka objek yang berbeda sedikit saja dengan template tidak akan dikenali. Oleh karena itu, jutaan template yang spesifik perlu dibuat agar cocok dengan berbagai bentuk geometri yang kita lihat dan kenal.

Template Matching dapat dibagi antara dua pendekatan, yaitu : pendekatan berbasis fitur dan pendekatan berbasis template. Pendekatan berbasis fitur menggunakan fitur pencarian dan template gambar seperti tepi atau sudut, sebagai pembanding pengukuran matrik untuk menemukan 
lokasi template matching yang terbagus di sumber gambar.

\section{Pendekatan Berbasis Fitur}

Sebuah pendekatan berbasis fitur dapat dianggap pendekatan jika template gambar memiliki fitur yang kuat jika pencocokan di pencarian gambar bisa diubah dengan cara tertentu. Karena pendekatan ini tidak mempertimbangkan keseluruhan dari template gambar, komputasi dapat lebih efisien ketika bekerja dengan sumber gambar beresolusi lebih besar, sebagai pendekatan alternatif,

berbasis template, mungkin memerlukan pencarian titik - titik yang berpotensi untuk menentukan lokasi pencocokan yang terbaik.

\section{Pendekatan Berbasis Template}

Untuk template tanpa fitur yang kuat, atau ketika sebagian besar template gambar merupakan gambar yang cocok, sebuah pendekatan berbasis template mungkin efektif. Seperti disebutkan di atas, karena berbasis template, template matching berpotensi memerlukan sampling dari sejumlah besar poin, untuk mengurangi jumlah sampling poin dengan mengurangi resolusi pencarian dan template gambar oleh faktor yang sama dan melakukan operasi pada perampingan gambar yang dihasilkan (multiresolusi, atau piramida, pengolahan citra), menyediakan pencarian titik data dalam pencarian gambar sehingga template tidak harus mempunyai pencarian titik data, atau kombinasi keduanya.

\section{Keping Darah (Trombosit)}

Keping darah atau trombosit adalah sel anuclear nulliploid (tidak mempunyai nukleus) dengan bentuk tak beraturan dengan ukuran diameter $2-3 \mu \mathrm{m}$ yang merupakan fragmentasi dari megakariosit. Trombosit tersirkulasi dalam darah dan terlibat dalam mekanisme hemostatis tingkat sel dalam proses pembekuan dengan membentuk darah beku. Nilai normal jumlah trombosit berkisar antara 200.000 $300.000 \mathrm{sel} / \mathrm{mm}^{3}$, nilai bawah rentang tersebut dapat menyebabkan pendarahan, sedangkan nilai diatas rentang yang sama dapat meningkatkan resiko trombosis.

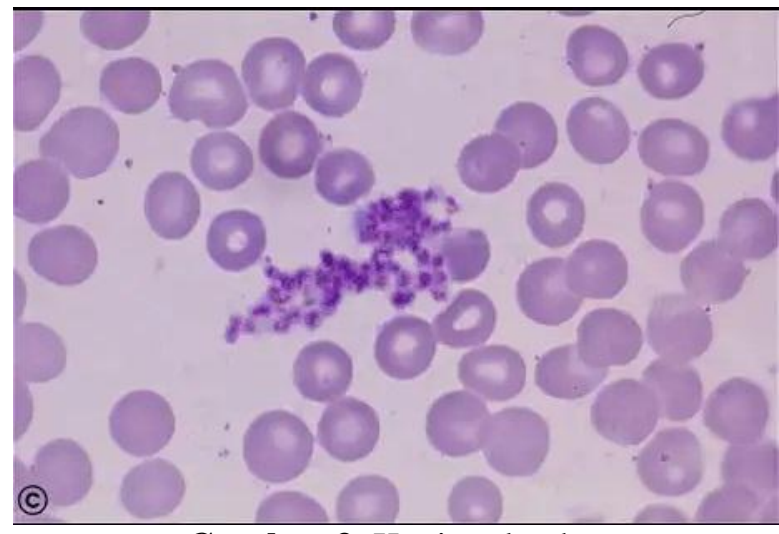

Gambar 3. Keping darah

\section{Demam Berdarah}

Penyakit demam berdarah dengue (DBD) adalah penyakit yang disebabkan oleh virus dengue I, II, III, dan IV yang ditularkan oleh nyamuk Aedes aegypti dan Aedes albopictus. Penyakit ini sering menyerang anak, remaja, dan dewasa yang ditandai dengan demam, nyeri otot dan sendi. Demam Berdarah Dengue sering disebut pula Dengue Haemoragic Fever ( DHF ).

Deman berdarah Dengue (DBD) adalah penyakit virus yang sangat berbahaya karena dapat menyebabkan penderita meninggal dunia dalam waktu yang sangat pendek (beberapa hari). Demam Berdarah Dengue (DBD) merupakan penyakit infeksi yang berakibat fatal dalam waktu yang relatif singkat. Penyakit ini tergolong sulit dibedakan dari penyakit demam berdarah yang lain. Hal ini disebabkan karena infeksi virus dengue yang menyebabkan DBD bisa bersifat asimtomatik atau tidak jelas gejalanya. Penyakit Deman Berdarah Dengue (DBD) menyerang semua umur dewasa maupun anak-anak. Dan penyakit ini termasuk ke dalam sepuluh penyebab perawatan di rumah sakit dan kematian pada anak- anak.

Penyakit ini masuk ke Indonesia sejak tahun 1968 melalui pelabuhan Surabaya, dan pada tahun 1980 DBD telah dilaporkan melanda seluruh provinsi di Indonesia (Hifzi, 2008) 
Jumlah kasus demam berdarah di Indonesia tercatat masih tinggi, bahkan paling tinggi dibanding negara lain di ASEAN. Data Kementrian Kesehatan (Kemenkes) RI mencatat jumlah kasus Demam Berdarah Dengue (DBD) pada tahun 2010 mencapai sekitar 150.000. Angka ini cenderung stabil pada tahun 2011, sehingga kasus DBD di Indonesia belum bisa dikatakan berkurang.

\section{Segmentasi}

Segmentasi merupakan bagian dari proses pengolahan citra. Proses segmentasi citra ini lebih banyak merupakan suatu proses pra pengolahan pada sistem pengenalan objek dalam citra. Segmentasi citra (image segmentation) mempunyai arti membagi suatu citra menjadi wilayahwilayah yang homogen berdasarkan kriteria keserupaan yang tertentu antara tingkat keabuan suatu piksel dengan tingkat keabuan piksel - piksel tetangganya, kemudian hasil dari proses segmentasi ini akan digunakan untuk proses tingkat tinggi lebih lanjut yang dapat dilakukan terhadap suatu citra, misalnya proses klasifikasi citra dan proses identifikasi objek.

\section{Sampel yang diteliti}

Dalam penelitian ini menggunakan tiga sampel. Sampel sel darah tersebut terdiri dari sampel sel darah normal, sel darah pasien dewasa yang teridentifikasi demam berdarah dan sampel darah pasien anak yang juga teridentifikasi demam berdarah yang didapatkan dari uji laboratorium. Pengambilan sampel mendapatkan perlakuan yang sama seperti pembesaran mikroskop, pencahayaan dan kamera yang digunakan.

Tabel berikut ini adalah citra sampel yang digunakan dalam penelitian ini :
Tabel 1. Sampel sel darah

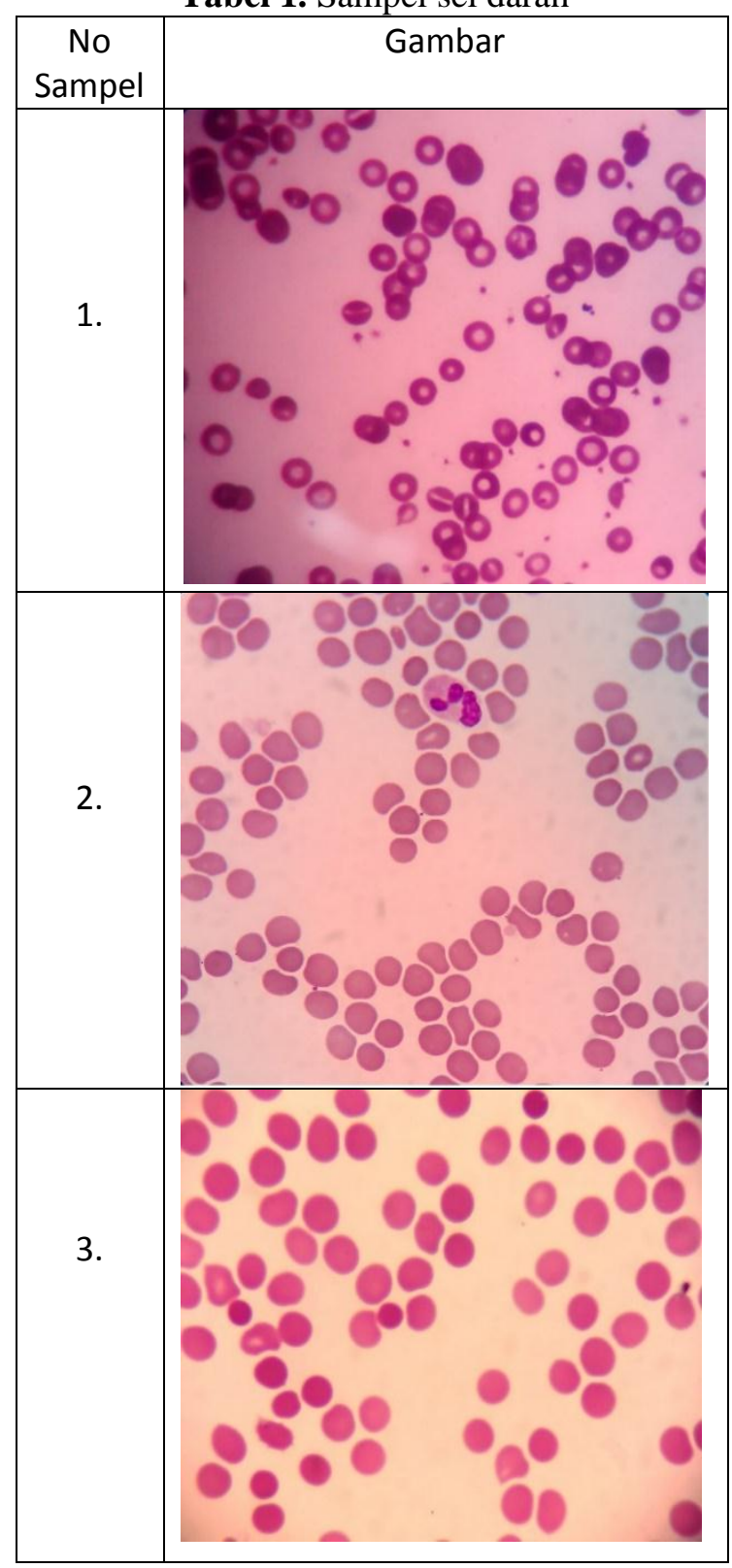

\section{Prosedur Penelitian}

Dilakukan untuk mendapatkan pemahaman tentang konsep-konsep teoritis yang berhubungan dengan judul penelitian. Studi literatur berupa diskusi dengan pembimbing, mengambil referensi dari internet dan buku-buku panduan, Studi literatur juga dilakukan terhadap aplikasi LabVIEW yang dalam penelitian ini menjadi sarana aplikatif.

\section{Penyusunan Algoritma Program}

Program yang dirancang dalam penelitian ini terbagi atas 3 (tiga) algoritma pokok, adalah : 
a) Algoritma segmentasi citra berdasarkan metode Hue Saturation Lightness. Pertama-tama dibuat algoritma untuk segmentasi citra dan dilanjutkan dengan algoritma untuk memisahkan antara objek sel darah normal dengan sel darah yang terinfeksi demam berdarah.

b) Algoritma manipulasi warna, untuk memudahkan dalam proses pelabelan objek maka masing-masing objek yang telah disegmen diberi warna yang sama.

c). Algoritma pelabelan objek. Masingmasing objek yang telah dimanipulasi diberi label yang berbeda yang bertujuan untuk menghitung jumlah masing-masing objek sel darah normal dengan sel darah terkena demam berdarah.

\section{Pembuatan Program}

Berdasarkan algoritma yang telah ditentukan diatas, dibuat program pengolahan citra perhitungan jumlah trombosit dengan menggunakan bahasa pemprograman LabVIEW.

\section{Pengujian Terhadap Hasil Pengolahan Citra}

Pengujian dilakukan dengan cara membandingkan citra atau image yang digunakan sebagai sumber input dan citra hasil pengolahan dengan menggunakan LabVIEW untuk mendapatkan posisi pelabelan objek dan hasil penghitungannya melalui simulasi program.

\section{Analisa Keluaran Sistem}

Analisa keluaran sistem didasarkan pada teknik analisa sistem. Keluaran dari sistem ini adalah berupa visualisasi citra hasil pengolahan dan menghitung jumlah sel objek yang ditemukan, Visualisasi citra berupa citra hasil pengolahan segmentasi $H S L$ dimana citra asli yang mengandung sel darah normal dan sel darah yang terkena demam berdarah setelah dilakukan segmentasi dan manipulasi warna masingmasing sel tersebut terpisah, jadi citra yang dikeluarkan adalah citra yang mengandung sel darah normal dan sel darah yang terinfeksi demam berdarah saja (Hifzi, 2008).

\section{Teknik Analisa Sistem}

Analisa yang dilakukan terhadap perhitungan otomatis menggunakan dua template berbeda yang diambil pada suatu sumber citra yang sama. Selanjutnya hasil tersebut akan dibandingkan dan dipilih nilai tertinggi dari masing-masingnya untuk kemudian dihitung total trombositnya dengan cara mengkalikan dengan angka faktor pengalinya. Terakhir, hasil tersebut akan diklasifikasikan berada pada tingkat DBD berapa.

\section{Perancangan Sistem}

Berikut ini merupakan flowchart untuk membangun sistem ini :

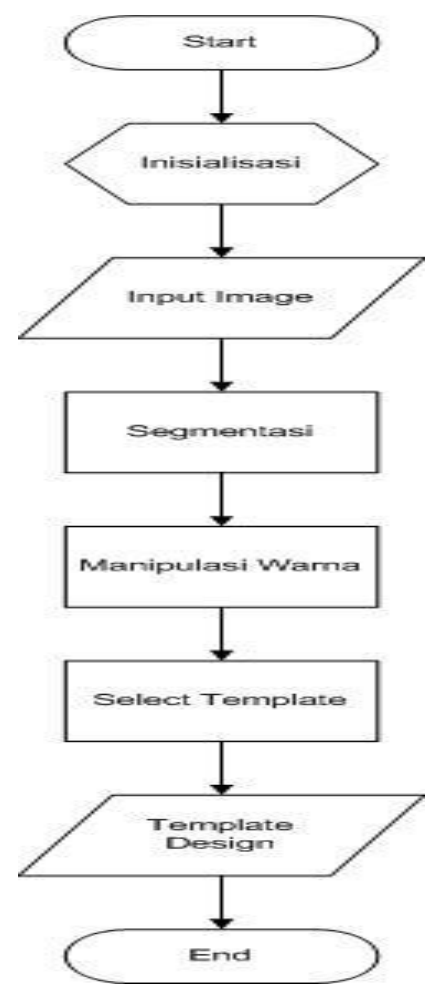

Gambar 4. Flowchart Template Design 


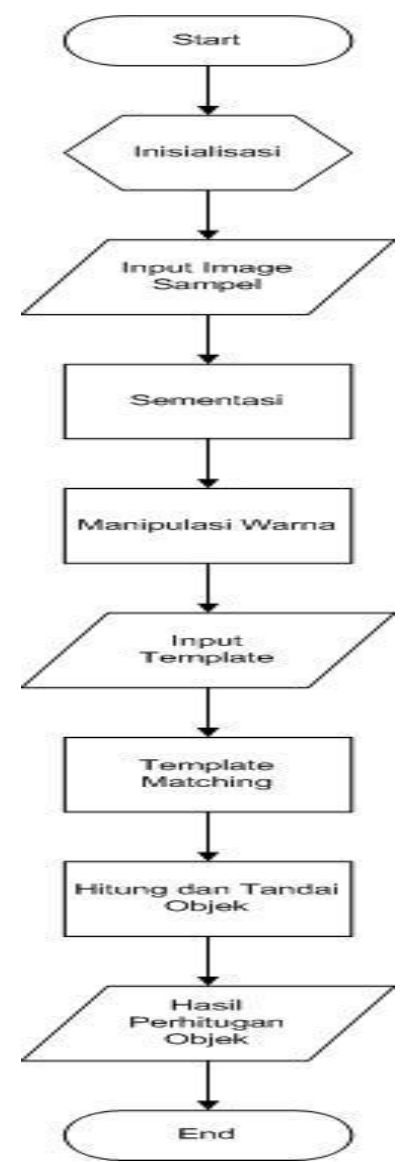

Gambar 5. Flowchart Perhitungan Objek

\section{HASIL}

Pembangunan sistem ini secara garis besar dilakukan dalam dua tahap, yaitu pembuatan template design dan perhitungan objek. Berhubung ada beberapa proses pada kedua sistem terdapat kesamaan, penjelasan akan disederhanakan seperti berikut ini :

\section{Loading Image Input}

Proses ini merupakan tahapan awal dari pemprosesan image yang akan dilakukan dimana sistem akan menghubungkan rancangan yang dibuat dengan penyimpanan komputer yang digunakan sehingga data citra yang terdapat pada komputer dapat diinputkan kedalam sistem.

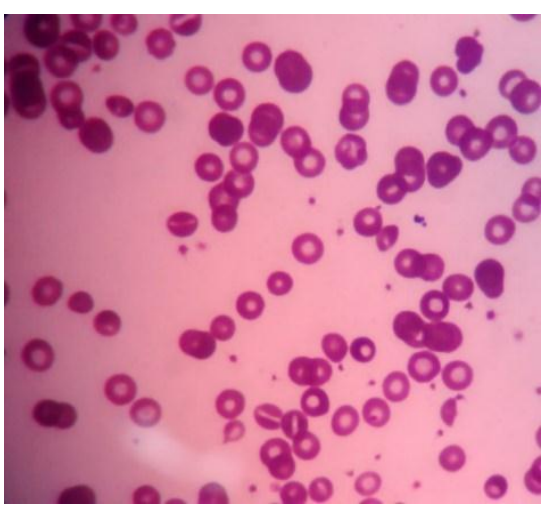

Gambar 6. Citra Sel darah Normal (Sampel 1)

\section{Proses Segmentasi}

Setelah dimasukan citra input, selanjutnya dilakukan proses segmentasi. Pada tahapan ini dilakukan proses segmentasi menggunakan segmentasi HSL dengan tipe Luminance Plane. Pemilihan jenis ini dikarenakan hasilnya yang tidak merusak objek didalam citra sehingga masih dapat dianalisa oleh mata manusia. Berikut ini merupakan hasil yang didapatkan dari proses segmentasi HSL.

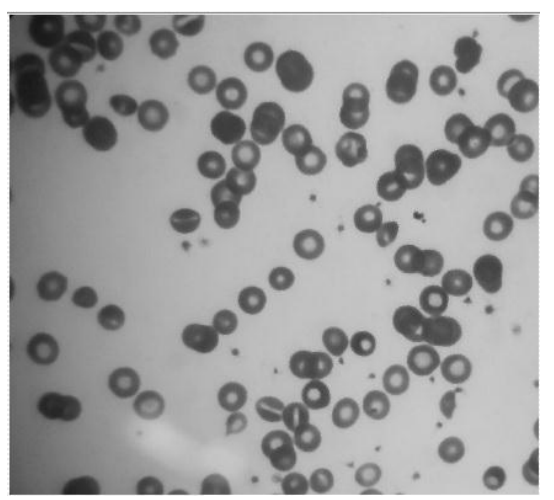

Gambar 7. Hasil Segmentasi HSL Sampel 1

\section{Manipulasi Warna}

Setelah dilakukan proses segmentasi, hasil tersebut akan melewati proses manipulasi warna pada tool LookUp Table dimana tipe manipulasi yang digunakan adalah Reverse. Berikut ini merupakan hasil dari proses manipulasi warna : 


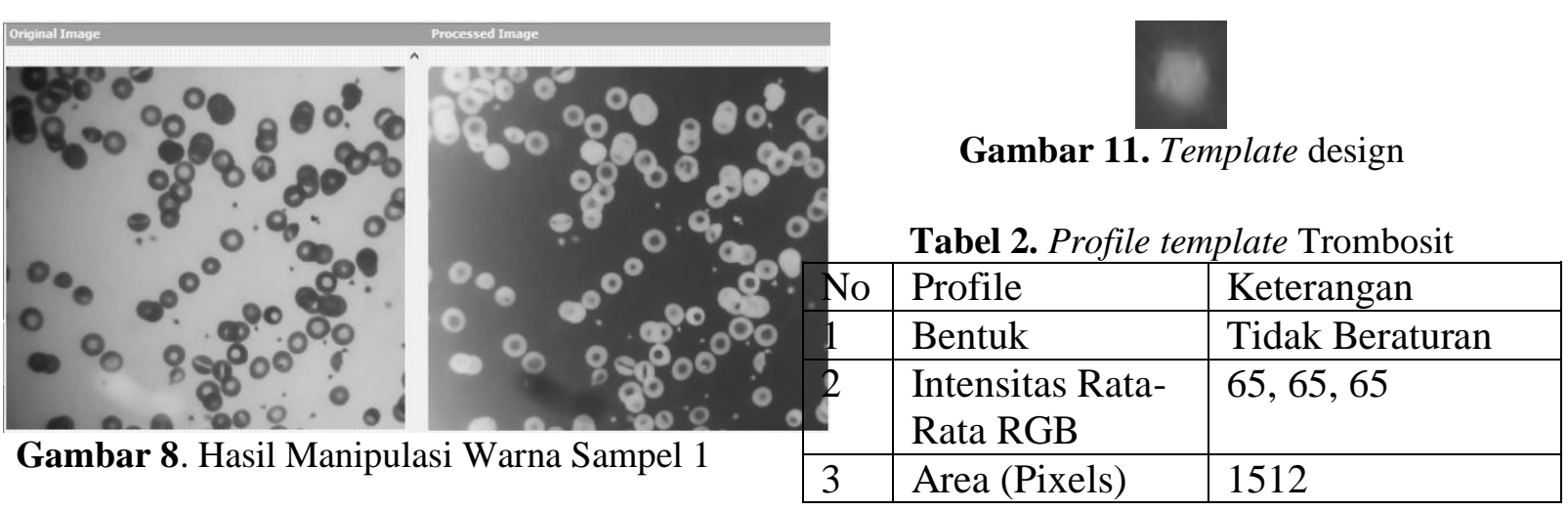

\section{Select Template}

Setelah didapatkan hasil manipulasi warna dari proses sebelumnya, selanjutnya dilakukan pemilihan template. Pada proses ini dilakukan ekstraksi image dengan cara memilih area pada citra yang merepresentasikan objek trombosit seperti pada gambar berikut :

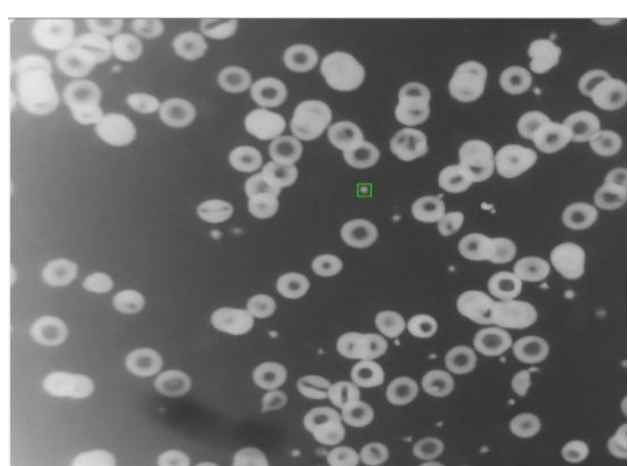

Gambar 9. Pemilihan Daerah Representasi Objek Trombosit

Selanjutnya dilakukan proses template editing, yaitu dengan cara memilih template region to ignore agar pembacaan saat proses template matching nantinya hanya berfokus pada objek trombosit tanpa terganggu oleh daerah sekitarnya. Proses yang dimaksud dapat dilihat pada gambar dibawah ini :

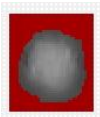

\section{Gambar 10. Template Editing}

Selanjutnya template yang telah diedit disimpan dalam format .PNG. Template yang telah disimpan dan akan digunakan dalam sistem ini dapat dilihat pada gambar dengan profile pada tabel 2 dibawah ini :

\section{Template Matching}

Pada tahapan ini dilakukan pencocokan objek pada sampel dan template yang telah dipilih. Setelah proses ini dilakukan, didapatkan hasil sebagai berikut :

\section{Sampel 1}

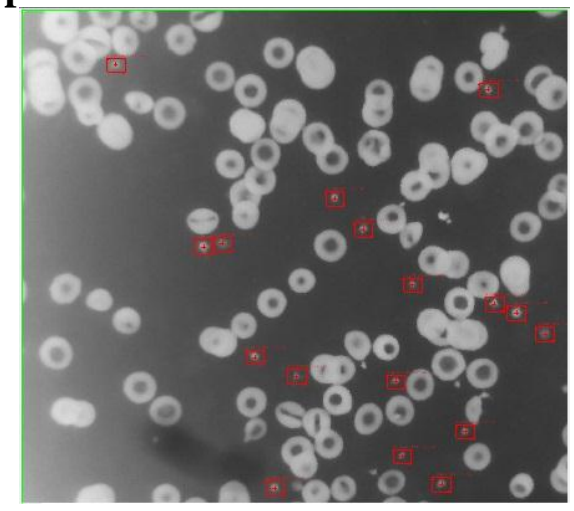

Gambar 12. Hasil Template Matching Template 1

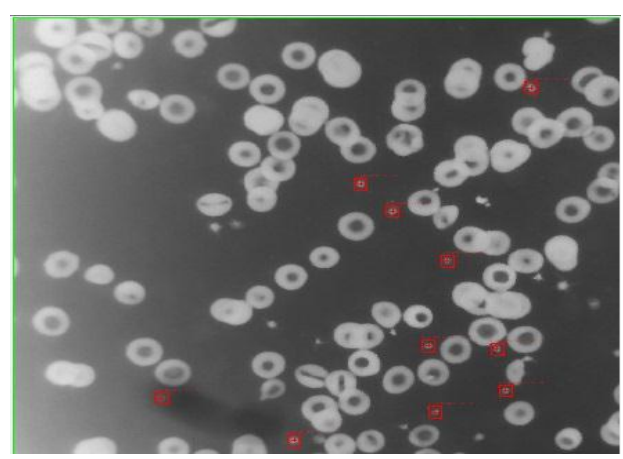

Gambar 13. Hasil Template Matching Template 2

\section{Hitung dan tandai objek sesuai template}

Setelah dilakukan proses template matching, selanjutnya dilakukan proses penghitungan dan penandaan objek. Pada proses ini diketahui posisi koordinat dari 
masing-masing objek yang bertanda persegi merah pada tabel posisi objek. Nomor terakhir dari kepala tabel menandakan hasil total objek trombosit yang terdeteksi dari proses sebelumnya yaitu template matching.

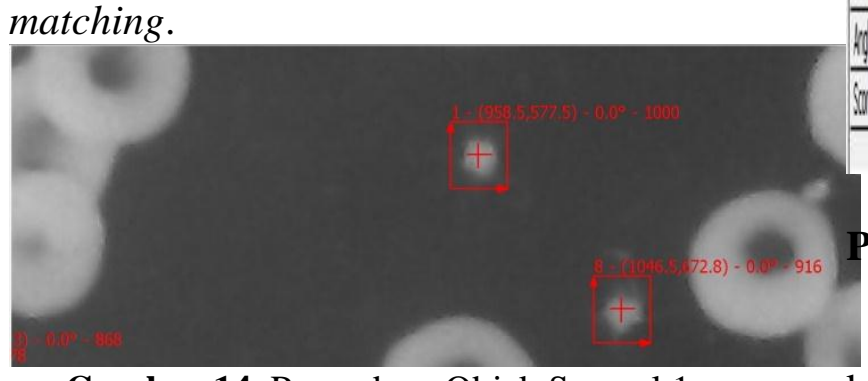

Tabel 4. Posisi Objek Trombosit Template 2

Gambar 14. Penandaan Objek Sampel 1

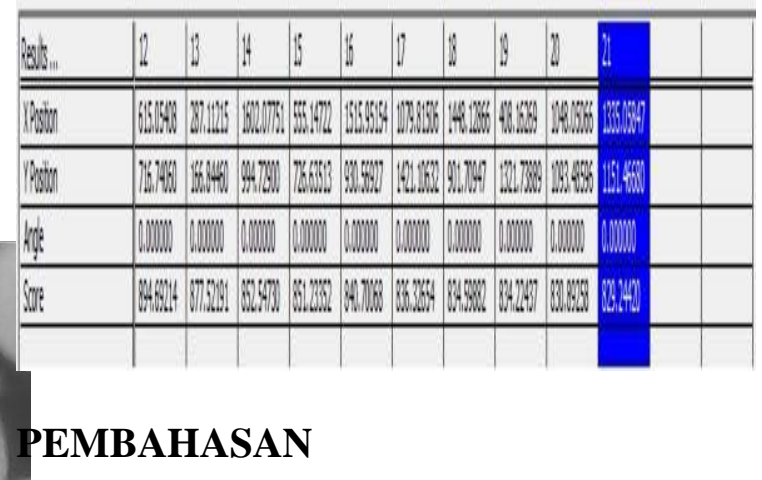

Setelah dilakukan pengujian terhadap ketiga sampel dengan dua template yang berbeda, dapat dibandingkan hasil

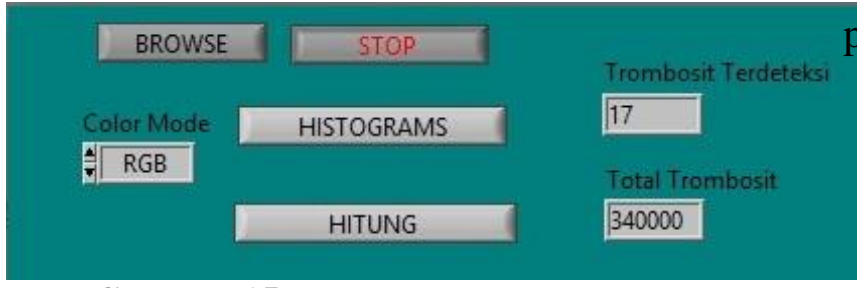
erhitungannya kedalam tabel dibawah ini :

Tabel 5. Perbandingan Hasil Perhitungan Menggunakan Tamplate 1 dan 2

Gambar 15. Penghitungan Otomatis Templatpada program

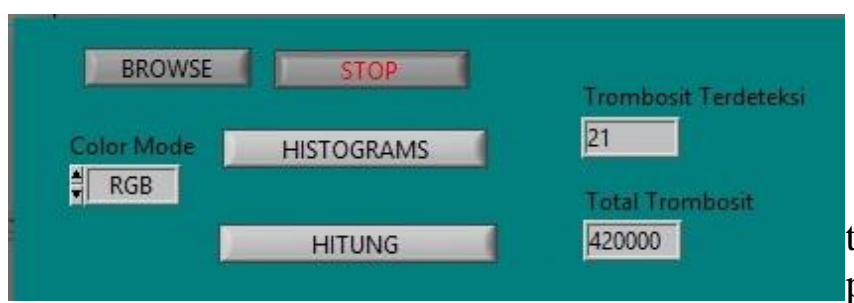

\begin{tabular}{ccc}
\hline Citra & Template & Template \\
Sampel & 1 & 2 \\
\hline & & \\
Sampel 1 & 17 & 21 \\
Sampel 2 & 3 & 3 \\
Sampel 3 & 0 & 1 \\
\hline
\end{tabular}

Dari hasil perhitungan menggunakan

Gambar 16. Penghitungan Otomatis Template 2 pada program template berbeda diatas ditemukan adanya perbedaan perhitungan. Seperti yang dapat dilihat pada sample 1 dan 3 . Hal ini dikarenakan selain dari ukuran objek template yang jika dilihat sedikit berbeda,

\section{Hasil Penghitungan Objek}

Setelah dilakukan template matching, selanjutnya dilakukan penghitungan objek secara otomatis. Adapun hasil yang didapatan adalah sebagai berikut :

\section{Sampel 1}

Tabel 3. Posisi Objek Trombosit Template 1 pengambilan ukuran batas objek dan latar belakang juga sangat menentukan.Karena terkadang ada objek trombosit yang berdempet dengan objek lainnya sehingga terjadi kesalahan pembacaan atau objek tidak terbaca. Atau dalam kasus lainnya, jika acuan region template terlalu besar, lalu pada saat template melakukan pencocokan daerah pusat ditemukan 
Tabel 6. Perbandingan Hasil Perhitungan Total Trombosit

\begin{tabular}{ccc}
\hline $\begin{array}{c}\text { Citra } \\
\text { Sampel }\end{array}$ & $\begin{array}{c}\text { Jumlah Objek } \\
\text { Trombosit }\end{array}$ & $\begin{array}{c}\text { Perhitungan Total } \\
\text { Trombosit } / \mathrm{mm}^{3}\end{array}$ \\
Sampel 1 & 21 & $\begin{array}{c}10 \text { lpmi } \times 2000 \times 21 \\
=420.000\end{array}$ \\
Sampel 2 & 3 & $\begin{array}{c}10 \mathrm{lpmi} \times 2000 \times 4 \\
=60.000\end{array}$ \\
Sampel 3 & 1 & $\begin{array}{c}10 \mathrm{lpmi} \times 2000 \times 1 \\
=20.000\end{array}$ \\
\hline
\end{tabular}

Dari hasil diatas dapat diklasifikasikan tingkat penyakit DBD. Untuk sampel 1 dikategorikan normal karena jumlah trombosit berada diatas 100.000 . Sedangkan untuk sampel 2 dengan jumlah total trombosit 60.000 dikategorikan berada pada derajat II. Hal ini perlu diperkuat dengan mengamati gejala yang timbul yaitu apabila jumlah trombosit berada diantara 50.000 - 100.000, maka cenderung akan terjadi pendarahan spontan. Jika hal ini benar, maka benar sampel 2 berada pada derajat II. Terakhir untuk sampel 3 dengan jumlah total trombosit 20.000 dikategorikan berada pada derajat III. Gejala yang perlu diperhatikan untuk menguatkan kebenaran hasil adalah jika dijumpai kegagalan sirkulasi yaitu nadi cepat dan lemah, tekanan nadi menyempit disertai gejala derajat II, maka dapat dipastikan bahwa sampel 3 benar berada pada derajat III.

\section{SIMPULAN}

1. Sebelum dilakukan proses template matching dan perhitungan, citra sampel perlu melewati beberapa pemprosesan diantaranya segmentasi dan manipulasi warna dimana segmentasi berfungsi untuk memisahkan antara objek dan latar belakang sedangkan manipulasi warna untuk meningkatkan kontras dan menyelaraskan warna.

2. Pada proses template matching dan perhitungan, sistem mampu menemukan objek yang sesuai dengan template design meskipun terdapat beberapa sampel yang pembacaannya tidak maksimal seperti tidak terbaca sama sekali karena sampel telah melewati editing pelabelan sehingga objek yang seharusnya dihitung tertimpa watermark dari pelabelan.

3. Untuk pendeteksian objek yang berbeda pada satu citra atau image diperlukan lebih template yang berbeda pula untuk menjamin keakuratan hasil pendeteksian objek.

4. Hasil penghitungan objek pembentuk sel keping darah pada system dengan perhitungan manual menunjukkan perbedaan. Hal ini disebabkan karena pada perhitungan manual hanya mengandalkan kemampuan visual dari pengamat. Sedangkan perhitungan dari system dilakukan secara otomatis menggunakan system yang dirancang menggunakan LabVIEW.

\section{SARAN}

1. Sampel yang diolah harus mendapat perlakuan yang sama pada saat pengambilannya seperti ukuran pembesaran mikroskop, pencahayaan dan kamera yang digunakan.

2. Dalam penentuan klasifikasi tingkat keparahan penyakit DBD juga sangat diperlukan peran dokter karena acuan diagnosa tidak hanya dari hasil penghitungan trombosit, namun juga tanda-tanda atau gejala yang timbul pada pasien.

3. Pemilihan region template yang merepresentasikan objek yang akan dihitung harus dilakukan dengan hatihati agar hasil penghitungan objek yang didapatkan akurat.

4. Untuk penggunaan software LabVIEW, disarankan untuk menggunakan PC dengan spesifikasi tinggi agar pada saat menjalankan program tidak terjadi hang pada PC karena software yang dijalankan cukup berat.

\section{DAFTAR PUSTAKA}

Hartadi Diaz, Sumardi, Isnanto Rizal, R, 2004,Simulasi Penghitung Jumlah Sel 
Darah Merah, Tugas Akhir, Jurusan Teknik Elektro UNDIP.

Hifzi Al, 2008, Simulasi Perhitungan Jumlah Sel Pembentukan Darah Menggunakan Teknik Segmentasi Amplitudo, Tugas Akhir Program Studi Teknik Telekomunikasi, Universitas Andalas, Padang.

Munir Rinaldi, 2006, Jurnal, Aplikasi Image Thresholding untuk segmentasi objek, Seminar, SNAPTI - ISSN: 1907-5022, Yogyakarta.

Munir Rinaldi, 2004. Pengolahan Citra Digital dengan Pendekatan Algoritmik. Informatika Bandung.

Sugianto, Soegeng, dkk, 2010, Uji Klinik Multisenter Sirup Ekstrak Daun Jambu biji pada Penderita Demam Berdarah Dengue, Medicinus Vol 23, No 1 Edition March-May 2010, ISSN 1979$391 X$.

Y. Amelia, K. Rahmadi 2015, Jurnal, Penentuan Klasifikasi Tingkat Stadium Demam Bersarah Dengue (Dbd) Berdasarkan Jumlah Sel Darah Putih Berbasis Image Processing. Vol 10, No. 2, Oktober 2015. ISSN : 18583709

R. Adollah, M.Y. Mashor, N.F. Mohd Nasir, H. Rosline, H. Mahsin, H. Adilah, 2008, Blood Cell Image Srgmentation: A. Review, Biomed, Proceedings 21, pp.141-144, 2008

http://www.google.co.id/e-

smartschool.html. Fungsi darah. Diakses tanggal 24 Januari 2013

http://www.hematologyatlas.com/seq32.ht $\underline{\mathrm{m}}$ diakses tanggal 24 Januari 2014
Pratt, William K. 2001. Digital Image Processing, $3^{\text {rd }}$ Ed. New York. John Wiley \& Sons. 